\title{
Production of exopolysaccharides from novel marine bacteria and anticancer activity against hepatocellular carcinoma cells (HepG2)
}

\author{
Mohsen S. Asker ${ }^{1 *}$, Osama H. El Sayed', Manal G. Mahmoud', Shaymaa M. Yahya², Sahar S. Mohamed', \\ Manal S. Selim, Mohamed S. El Awady ${ }^{1}$, Salma M. Abdelnasser ${ }^{1}$ and Mostafa M. Abo Elsoud ${ }^{1}$
}

\begin{abstract}
Background: The aim of the current study based on the production and characterization of exopolysaccharides (EPSs) isolated from marine sediment of the Mediterranean and Red Seas is to study its cytotoxic activity against HepG2 cells.

Results: Eleven isolates have the ability to produce EPSS and also decreased the viability of HepG2 cell line in different manners. The five most promising isolates that produce high yield of EPSs and high cytotoxicity were identified by $16 \mathrm{~S}$ RNA as Brevundimonas subvibrioides MSA1, Bacillus thuringiensis E4, Bacillus amyloliquefaciens MGA2, Pseudomonas fluorescens SGA3, and Advenella Kashmirensis NRC-7. The chemical composition of the following EPSs (M1, M3, M6, M15, M19, E2, E4, E10, S5, S7, and S11) demonstrates that they are acidic sulfated heteropolysaccharides with different relative ratios of monosugars of glucose, mannose, galactose, glucouronic acid, and mannouronic acid. The average molecular weights from $1.94 \times 10^{4}$ to $7.95 \times 10^{5} \mathrm{~g} / \mathrm{mol}$ and the number average molecular weight from $1.51 \times 10^{4}$ to $7.53 \times 10^{5} \mathrm{~g} / \mathrm{mol}$. FTIR spectrum of the five EPSs indicated the presence of sulfate and carboxylic groups in different percentages.
\end{abstract}

Conclusions: The EPSs produced from marine bacteria are very promising for treating the HepG2 cells.

Keywords: Exopolysaccharides, Marine bacteria, Cytotoxicity, Hepatocellular carcinoma cells

\section{Background}

Essential liver tumor is the fifth most normal threat on the planet, with a worldwide yearly occurrence of around one million new patients (Shah and Bhowmick 2006). The malady wins in parts of Asia and Africa, yet seems overflowing in numerous European nations lately. As need be, it is encouraged to investigate another approach for improvement of a viable treatment against this illness. In spite of the fact that chemotherapy is one of the compelling medication strategies against liver cancer, chemotherapeutic operator prompts serious unfavorable impacts while murdering tumor cells (Drake and

\footnotetext{
* Correspondence: mohsenmsa@yahoo.com

${ }^{1}$ Microbial Biotechnology Department, Genetic Engineering and

Biotechnology Division, National Research Centre, Dokki, Egypt

Full list of author information is available at the end of the article
}

Antonarakis 2010). At that point, it is extremely essential to discover novel bacteria hostile to tumor specialists with high natural exercises and low danger to host. Natural products have been the pillar of tumor chemotherapy for as far back as 30 years and are probably going to give a considerable lot of the lead structures, and these will be utilized as layouts for the development of novel compounds with upgraded organic properties (Wani et al. 1971). The marine condition is a rich wellspring of remarkable bioactive compounds, for example, exopolysaccharides (EPSs) from microorganisms with boundless chemical and functional varieties. Pretty much 30,000 regular items have been segregated from marine organisms, and a few of the medication competitors are right now in clinical trials. Marine microorganisms frequently deliver bioactive substances 
with novel capacities and structures in view of their uncommon living conditions (Fenical 1993). EPSs from marine microorganisms are important to new medication disclosure (Miranda et al. 2008; Xu et al. 2009; Casillo et al. 2018). EPSs have different biological activities with low poisonous quality and have pulled in broad considerations of researchers (Huang et al. 2012; Wang et al. 2014; Cai et al. 2017). As of late, various investigations on the mechanism of action of EPSs have exhibited that EPSs could repress the tumor development in vivo for their immunomodulatory activities. They apply hostility to tumor movement by boosting the host's common insusceptible resistance. Along these lines in this investigation, different EPSs segregated from various marine bacteria were tried for their capacity on liver malignancy cell line (Yang et al. 2013; Peng et al. 2014; Yang et al. 2014). The present study aimed to isolate and identify new marine bacterial strains that produced EPSs. The cytotoxic effects of these crude EPSs were tested against hepatocellular carcinoma (HepG2) cells.

\section{Methods}

\section{Sampling}

Three samples were collected from marine sediment at different locations from (Mediterranean Sea) Sidi Bishr beach at Alexandria, (Red Sea) Marsa-Alam (rhizosphere around the mangrove tree) areas, and El-Ain El-Sokhna beach in September 2014.

\section{Isolation of bacteria}

The collected samples $(10 \mathrm{~g})$ were placed in $100 \mathrm{~mL}$ of sterile seawater and homogenized by shaking at 200 rpm for $15 \mathrm{~min}$, and a serial dilution was performed (Hayakawa and Nonomura 1987). Finally, $50 \mu \mathrm{L}$ of the supernatant of each dilution was inoculated on marine nutrient agar, and the plates were incubated at $37^{\circ} \mathrm{C}$ for $24 \mathrm{~h}$. The colonies that appeared per plate of each sample were subjected to purification. Isolated microorganisms showing mucous growth on these media were further screened for EPS production by inoculation into shake flasks.

\section{Screening for production of EPSs}

Isolates were screened for production of EPSs in a different liquid media which were composed of the following ingredients $(\mathrm{g} / \mathrm{L})$ : peptone 4.0 , yeast extract 2.0 , and sucrose 20 (Jiang et al. 1999). The ingredients were dissolved in $750 \mathrm{~mL}$ seawater. After adjusting the $\mathrm{pH}$, the final volume was completed up to $1 \mathrm{~L}$ with distilled water. After incubation at $37^{\circ} \mathrm{C}$ for 3 days, the culture medium was centrifuged at $5000 \mathrm{rpm}$ for $20 \mathrm{~min}$ (Sigma Laborzentrifugen, $2 \mathrm{~K} 15)$ to remove bacterial cells. Trichloroacetic acid (5\%) was added and left overnight at $4{ }^{\circ} \mathrm{C}$ and centrifuged at $5000 \mathrm{rpm}$ again. The $\mathrm{pH}$ of the clear solution was adjusted to 7.0 with $\mathrm{NaOH}$ solution and dialyzed three times against distilled water. The supernatant was completed to four volumes with absolute ethanol and left overnight at $4{ }^{\circ} \mathrm{C}$. The precipitated polysaccharides were separated by centrifugation at $5000 \mathrm{rpm}$, washed twice with acetone, dehydrated by ether, and finally dried under vacuum at $40^{\circ} \mathrm{C}$ (Shene et al. 2008).

\section{Cytotoxic effects of isolated EPSs on HepG2 cells Cell propagation and maintenance}

Hepatocellular carcinoma HepG2 cells were purchased from ATCC (American Type Culture Collection) and maintained in the proper conditions. The cells were cultured in Dulbecco's modified Eagle's medium (DMEM) (Lonza, Belgium) supplemented by $10 \%$ fetal bovine serum, $4 \mathrm{mM} \mathrm{L}$-glutamine, $100 \mathrm{U} / \mathrm{mL}$ penicillin, and $100 \mu \mathrm{g} / \mathrm{mL}$ streptomycin sulfate at $37^{\circ} \mathrm{C}$ in a humidified incubator with $5 \% \mathrm{CO}_{2}$. The cells were harvested after trypsinization $(0.025 \%$ trypsin and $0.02 \%$ EDTA) and washed twice with Dulbecco's phosphate-buffered saline (DPBS). When the cell density reached approximately $80 \%$, cells were split for further culture. The experiments were made up when the cells were in the logarithmic growth phase.

\section{Cytotoxicity assay}

Cell viability was measured by neutral red uptake assay (Repetto et al. 2008). The neutral red uptake assay provides a quantitative estimation of the number of viable cells in a culture. It is based on the ability of viable cells to incorporate and bind the supravital dye neutral red in the lysosomes. The cells were incubated with various concentrations of the test compounds $(125,250,500$, and $1000 \mu \mathrm{g} / \mathrm{mL}$ ) for $48 \mathrm{~h}$ at a cell density of $10^{4}$ cells/ well of a 96-well plate. Using the relation between used concentrations and neutral red intensity value, $\mathrm{IC}_{50}$ of tested compounds was calculated (Repetto et al. 2008). Four parameter equation logistic curve was used (log concentration vs. percentage cell growth as compared to control cells). For the untreated cells (negative control), medium was added instead of the test compounds. A positive control doxorubicin $(\mathrm{Mr}=579.9)$ was used as cytotoxic natural agent giving 100\% inhibition. Dimethyl sulfoxide (DMSO) was the vehicle used for dissolution of tested compound, and its final concentration on the cells was less than $0.2 \%$. All tests and analyses were done in triplicate, and the results were averaged.

\section{Identification of promising isolates}

The promising isolates which produced high amounts of EPS were identified based on biochemical, morphological, and physiological characteristics of the potential 
producer as determined by adopting standard methods (Cappucino and Sherman 2004). The strains were confirmed with $16 \mathrm{~S}$ ribosomal RNA gene sequence and compared with other bacterial sequences by using NCBI BLAST. Taxonomic affiliation of the sequences was retrieved from classifier program of ribosomal database project (RDP-II) (Maidak et al. 1997; Tamura et al. 2007). RDP-II hierarchy is based on the new phylogenetically consistent higher order bacterial taxonomy.

\section{Production, separation, and purification of EPSs}

The EPSs were produced from the five strains Brevundimonas subvibrioides MSA1, Bacillus thuringiensis E4, Bacillus amyloliquefaciens MGA2, Pseudomonas fluorescens SGA3, and Advenella Kashmirensis NRC-7. Therefore, the crude EPS was precipitated with 1,2,3,4-volumes absolute ethanol, and supernatant was recovered by centrifugation. EPS fractions named MSA1, E4, MGA2, SGA3, and NRC7 were obtained from the supernatant mentioned above by precipitating with ethanol. The main fractions were collected, dialyzed, dried, and used for further analysis.

\section{Chemical structure of EPSs \\ Analysis of chemical composition}

The EPS samples $(30 \mathrm{mg}$ ) were hydrolyzed with $88 \%$ $\mathrm{HCOOH}(5 \mathrm{~mL})$ at $100^{\circ} \mathrm{C}$ in a sealed tube for $5 \mathrm{~h}$. Excess acid was removed by flash evaporation on a water bath at a temperature of $40^{\circ} \mathrm{C}$ and co-distilled with water $(1 \mathrm{~mL} \times 3)$ (Sudhamani et al. 2004). Then, the hydrolyzed monosugars were extracted with absolute ethanol. The purified hydrolysis monosugars were analyzed by HPLC (Agilate Pack, serics1, 200), equipped with Aminex carbohydrate HP-87C column $(300 \times 7.8 \mathrm{~mm})$. Deionized water was used as the mobile phase at flow rate $1 \mathrm{~mL} / \mathrm{min}$. Chromatographic peaks were identified by comparing the retention times with the respective retention times of known standard reference material. Retention time and peak area were used to calculate sugar concentration by the data analysis of Agilat Packard (Randall et al. 1989). Total sugar content was determined by the phenol- $\mathrm{H}_{2} \mathrm{SO}_{4}$ method using glucose as the standard (Dubois et al. 1956). Protein content was measured by the method of Bradford (1976). Sulfate ester content was measured using the turbidimetric method with sodium sulfate as standard (Therho and Hartiala 1971). Uronic acid content was determined by the carbazole- $\mathrm{H}_{2} \mathrm{SO}_{4}$ method using glucouronic acid as standard (Bitter and Muir 1962).

\section{Fourier transform infrared spectroscopy (FTIR)}

Fourier transform infrared was obtained by grinding a mixture of EPS sample with dry $\mathrm{KBr}$ and pressing in a mold. An IR spectrum was recorded on a Fourier transform infrared spectrophotometer Brucker Scientific 500IR (Ray 2006).

\section{Average molecular weight determination}

The average molecular weight $(M w)$ of the EPSs was determined by high-performance liquid chromatography (HPLC, Agilent 1100 Series System, Hewlett-Packard, Germany) with refractive index (RI) detection. The EPS $(10 \mathrm{mg})$ was dissolved in $2 \mathrm{~mL}$ of solvent and filtrated by filter 0.45 , then the EPS solution was put in a GPC device (Jun et al. 2009). The polydispersity index (PI) was calculated from the $M w / M n$ ratio (You et al. 2013). Number average molecular weight $(\mathrm{Mn})$ and weight average molecular weight $(M w)$ were directly calculated according to the definition of $M n$ and $M w$ using molecular weight and RI signal values at each elution volume (You et al. 2013).

\section{Results}

\section{Screening for production of EPSs}

Twenty isolates of marine bacteria were isolated from Marsa-Alam, El-Ain El-Sokhna, and Sidi Bishr. The bacterial isolates gathered from different marine sediments and displaying mucous morphology on marine supplement agar medium were inoculated into $50 \mathrm{~mL}$ of nutrient broth under shaking. Marine bacterial isolates were screened for their ability to deliver EPS (Table 1). The most elevated yield of EPS (7.5, 8.2, 8.1, 7.6, 8.2, 9.0, 8.0, 8.5, 9.2, 7.9, 7.3, 8.0, and $9.1 \mathrm{~g} / \mathrm{L})$ was acquired by

Table 1 Production of EPS from isolates

\begin{tabular}{|c|c|c|c|c|c|c|c|c|}
\hline Location & Code & EPS (g/L) & Location & Code & EPS (g/L) & Location & Code & EPS ( $\mathrm{g} / \mathrm{L})$ \\
\hline \multirow[t]{7}{*}{ Marsa-Alam } & M1 & 7.5 & El-Ain El-Sokhna & E2 & 8.0 & Sidi Bishr & S5 & 7.3 \\
\hline & M3 & 8.2 & & E4 & 8.5 & & S7 & 5.8 \\
\hline & M6 & 8.1 & & E8 & 4.8 & & S9 & 6.4 \\
\hline & M13 & 7.5 & & E10 & 9.2 & & S11 & 3.8 \\
\hline & M15 & 7.6 & & E14 & 4.5 & & $\mathrm{~S} 12$ & 8.0 \\
\hline & M18 & 8.2 & & E16 & 5.8 & & S17 & 9.1 \\
\hline & M19 & 9.0 & & E20 & 7.9 & & & \\
\hline
\end{tabular}


isolates M1, M3, M6, M15, M18, M19, E2, E4, E10, E20, S5, S12, and S17, separately.

\section{In vitro cytotoxicity on HepG2 cell line}

The EPSs from 20 isolates have been examined for their anticancer activity against hepatocellular carcinoma HepG2 cell line. This was done using the ability of viable cells to incorporate and bind the survival dye neutral red in lysosomes. In an essential screening test, EPS (M1, M3, M6, M15, M19, E2, E4, E10, S5, S7, and S11) decreased the viability of HepG2 cell line in concentrations 125, 250, 500, and $1000 \mu \mathrm{g} / \mathrm{mL}$ (Fig. 1a-d and Table 2).

\section{Identification of promising isolates}

The promising isolates which give high yield of EPSs and cytotoxicity against HepG2 (M19, E4, M6, E2, S7) were

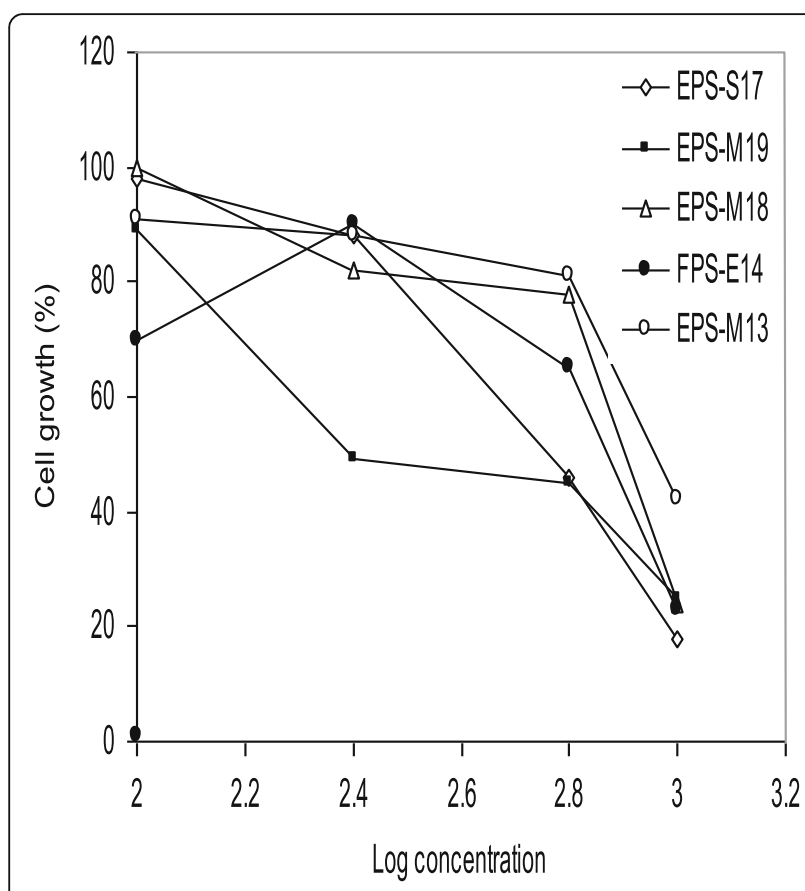

(a)

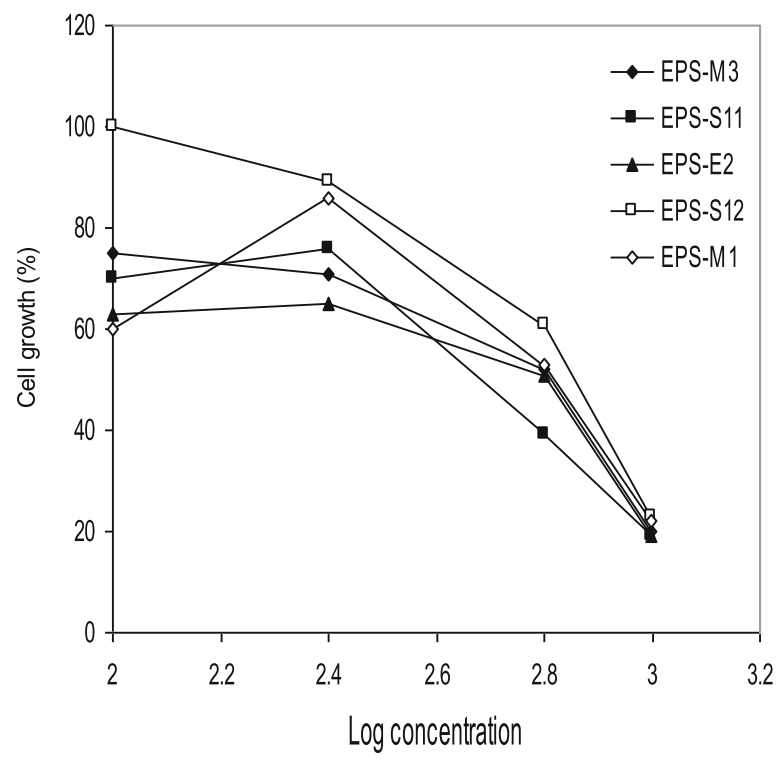

(c)

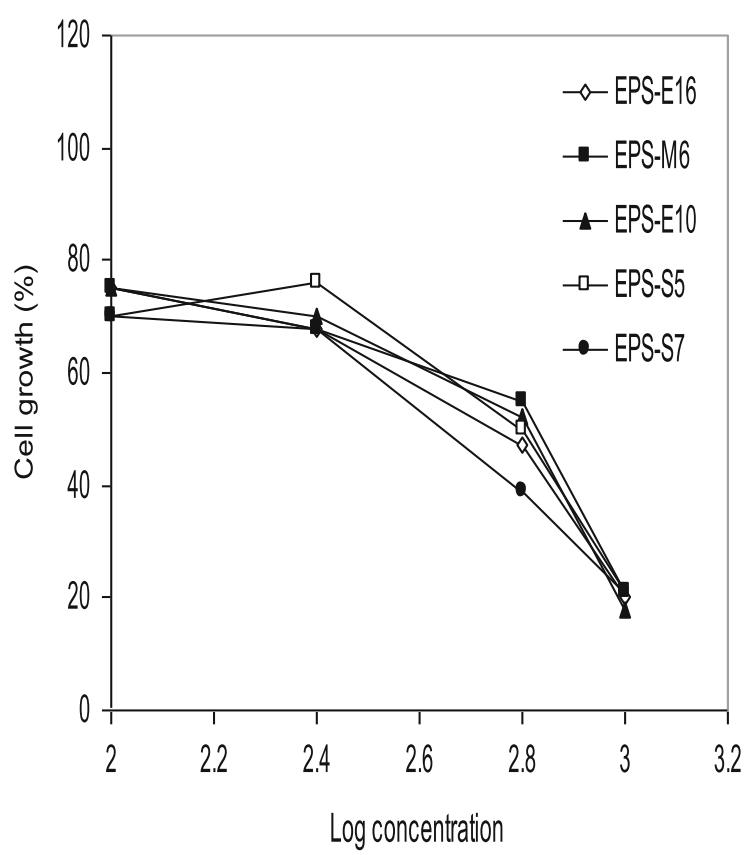

(b)

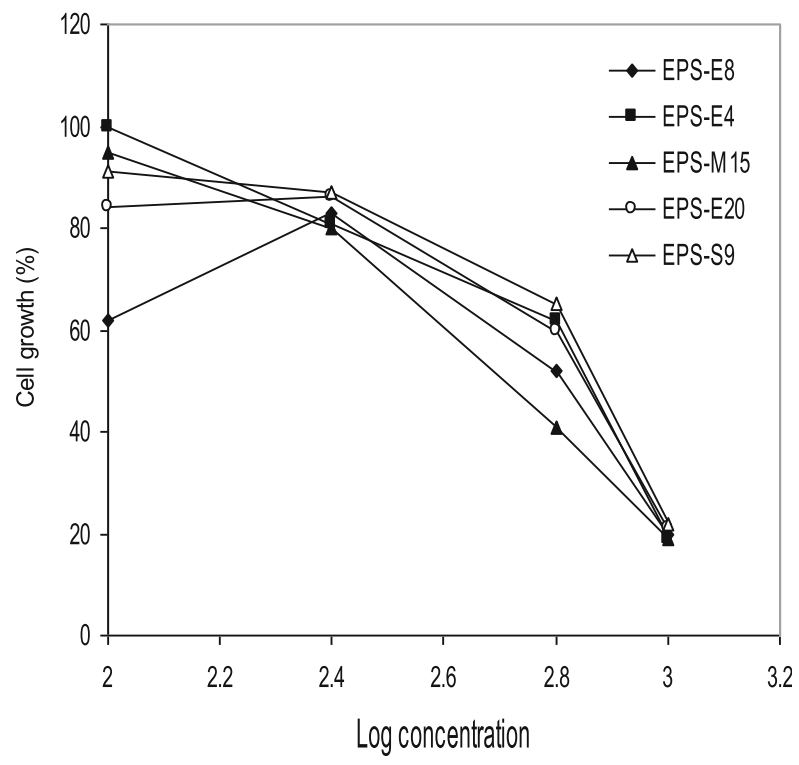

(d)

Fig. 1 Effects of EPSS a S17, M19, M18, E14, and M13; b E16, M6, E10, S5, and S7; c M3, S11, E2, S12, and M1; and d E8, E4, M15, E20, and S9 on HepG2 cell line at $48 \mathrm{~h}$ 
Table 2 In vitro cytotoxicity on HepG2 cell line

\begin{tabular}{llllll}
\hline Code & $\mathrm{IC}_{50}(\mu \mathrm{g} / \mathrm{mL})$ & Code & $\mathrm{IC}_{50}(\mu \mathrm{g} / \mathrm{mL})$ & Code & $\mathrm{IC}_{50}(\mu \mathrm{g} / \mathrm{mL})$ \\
\hline M1 & 524.0 & E2 & 537.0 & $\mathrm{~S} 5$ & 436.0 \\
M3 & 549.0 & E4 & 630.9 & $\mathrm{~S} 7$ & 389.0 \\
M6 & 562.0 & E8 & 630.0 & $\mathrm{~S} 9$ & 676.0 \\
M13 & 891.0 & E10 & 549.0 & $\mathrm{~S} 11$ & 407.0 \\
M15 & 501.0 & E14 & 660.0 & $\mathrm{~S} 12$ & 707.0 \\
M18 & 724.0 & E16 & 467.0 & S17 & 467.0 \\
M19 & 309.0 & E20 & 640.0 & Drug & 2.1 \\
\hline
\end{tabular}

distinguished in light of biochemical, morphological, and physiological characteristics (Table 3). The phylogenetic investigation of $16 \mathrm{~S}$ rDNA exhibited that the bacteria had a place with the gamma subdivision of the Proteobacteria phylum and is firmly identified as Brevundimonas subvibrioides MSA1 (M19), Bacillus thuringiensis E4 (E4), Bacillus amyloliquefaciens MGA2 (M6), Pseudomonas fluorescens SGA3 (E2) and Advenella Kashmirensis NRC-7 (S7), with accession numbers KP064319, KP096416, KP064320, KP064321, and KM017000, separately.

\section{Chemical structure of EPSs \\ Chemical analysis of EPS fractions}

The yields of the EPSs from Brevundimonas subvibrioides MSA1, Bacillus thuringiensis E4, Bacillus amyloliquefaciens MGA2, Pseudomonas fluorescens SGA3, and Advenella Kashmirensis NRC-7 were 7.5, 8.5, 8.2, 9.0, and $5.8 \mathrm{~g} / \mathrm{L}$ broth media, individually. The main fractions MGA2, MSA1, E4, SGA3, and NRC7 were purified by fraction with ethanol precipitation from the crude EPSs. The fractions MGA2, MSA1, E4, SGA3, and NRC7 were gathered for further investigation of structure and activity. MGA2, MSA1, E4, SGA3, and NRC7 had a negative response to the Bradford test. This outcomes demonstrate the absence of protein and/or nucleic acid. The average
Table 4 Molecular weights and polydispersity of EPS

\begin{tabular}{llll}
\hline EPSs & $\begin{array}{l}\text { Weight average } \\
\text { molecular } \\
\text { weight }(M w)\end{array}$ & $\begin{array}{l}\text { Number average } \\
\text { molecular } \\
\text { weight }(M n)\end{array}$ & $\begin{array}{l}\text { Polydispersity } \\
(P I)(M w / M n)\end{array}$ \\
\hline MSA1 & $2.51 \times 10^{4}$ & $2.13 \times 10^{4}$ & 1.18 \\
E4 & $1.94 \times 10^{4}$ & $1.51 \times 10^{4}$ & 1.28 \\
MGA2 & $1.18 \times 10^{5}$ & $1.05 \times 10^{5}$ & 1.12 \\
SGA3 & $7.95 \times 10^{5}$ & $7.53 \times 10^{5}$ & 1.05 \\
NRC7 & $2.48 \times 10^{4}$ & $2.32 \times 10^{4}$ & 1.07 \\
\hline
\end{tabular}

molecular weights $(M w)$ and average molecular numbers $(\mathrm{Mn})$ of MGA2, MSA1, E4, SGA3, and NRC7 were $2.51 \times$ $10^{4}, 1.94 \times 10^{4}, 1.18 \times 10^{5}, 7.95 \times 10^{5}$, and $2.48 \times 10^{4} \mathrm{~g} / \mathrm{mol}$ and $2.13 \times 10^{4}, 1.51 \times 10^{4}, 1.05 \times 10^{5}, 7.53 \times 10^{5}$, and $2.32 \times 10^{4} \mathrm{~g} / \mathrm{mol}$, respectively (Table 4). Results from phenol- $\mathrm{H}_{2} \mathrm{SO}_{4}$ assay showed that MGA2, MSA1, E4, SGA3, and NRC7 contained 87.4, 90.2, 94.3, 97.5, and 97.1\% carbohydrate; 1.9, 2.7, 8.6, 7.3, and 13.3\% uronic acid; and $12.5,9.6,5.4,2.1$, and $2.8 \%$ sulfate, respectively (Table 5 ). These show that MGA2, MSA1, E4, SGA3, and NRC7 are acidic sulfated heteropolysaccharides. Concerning monosaccharide quantitative and qualitative determination, the use of HPLC is favored due to its sensitivity. MGA2, MSA1, E4, SGA3, and NRC7 are comprised of five distinct monosaccharides, including glucose, mannose, galactose, glucouronic acid, and mannouronic acid with molar ratios of 1.0:1.6:1.2:0.2:0.0; 2.3:1.0:0.0:0.2:0.0; 2.52:1.0:0.0:0.0:1.4; 3.6:0.0:1.0:0.5:0.4; and 1.0:2.5:0.0: 1.8:0.6, respectively (Table 5).

\section{FTIR analysis of MGA2, MSA1, E4, SGA3, and NRC7}

FTIR analysis of the EPS fractions MGA2, MSA1, E4, SGA3, and NRC7 has unmistakably demonstrated a number of peak characteristics of carbonyl compounds. The intensity of bands around $3431 \mathrm{~cm}^{-1}$ was assigned to $\mathrm{vOH}$ stretching frequency, and as expected, it was

Table 3 Morphology and biochemical characterization of promising isolates

\begin{tabular}{|c|c|c|c|c|c|c|c|c|}
\hline Code & Gram staining & Shape form & Starch hydrolysis & V.P test & $\mathrm{H}_{2} \mathrm{~S}$ test & Citrate test & Indol test & Nitrate test \\
\hline$\overline{M 1}$ & Positive & Short rods & - & + & + & - & - & - \\
\hline E2 & Negative & Short rods & + & + & + & - & - & - \\
\hline M3 & Positive & Bacilli & + & - & - & + & - & - \\
\hline E4 & Positive & Short rods & + & - & + & - & - & - \\
\hline S5 & Positive & Bacilli & - & - & + & - & - & - \\
\hline M6 & Positive & Bacilli & + & + & - & + & - & - \\
\hline S7 & Positive & Short rods & - & & + & + & - & + \\
\hline E10 & Positive & Bacilli & + & - & - & + & - & + \\
\hline M15 & Positive & Bacilli & - & + & + & - & - & + \\
\hline M19 & Positive & Bacilli & + & - & + & - & - & + \\
\hline S11 & Positive & Bacilli & + & - & - & + & - & + \\
\hline
\end{tabular}


Table 5 The uronic acid, sulfate percentage, and molar ratio of monosaccharides for MGA2, MSA1, E4, SGA3, and NRC7

\begin{tabular}{llllllll}
\hline EPS & Sulfate (\%) & Uronic acid (\%) & \multicolumn{2}{l}{ Molar ratio (MR) } \\
\cline { 5 - 8 } & & & Glucose & Mannose & Galactose & Glucouronic acid & Mannouronic acid \\
\hline MSA1 & 12.5 & 1.9 & 1.0 & 1.6 & 1.2 & 0.2 & 0.0 \\
E4 & 9.6 & 2.7 & 2.3 & 1.0 & 0.0 & 0.3 & 0.0 \\
MGA2 & 5.4 & 8.6 & 2.5 & 1.0 & 0.0 & 0.0 & 1.4 \\
SGA3 & 2.1 & 7.3 & 3.6 & 0.0 & 1.0 & 0.5 & 0.4 \\
NRC7 & 2.8 & 13.3 & 1.0 & 2.5 & 0.0 & 1.8 & 0.6 \\
\hline
\end{tabular}

broad. The weak intensity of band attributed to $\mathrm{C}-\mathrm{H}$ group stretching $\left(\sim 2933 \mathrm{~cm}^{-1}\right)$ could also be noticed. Also, peaks at $1636 \mathrm{~cm}^{-1}$ and $1428 \mathrm{~cm}^{-1}$, for the asymmetric and symmetric stretching of carboxylate anionic groups, demonstrate the carboxyl groups in MGA2, MSA1, E4, SGA3, and NRC7. Absorption at $1429 \mathrm{~cm}^{-1}$ was possibly due to non-symmetric $\mathrm{CH}_{3}$ bending. The strong absorption at $1069 \mathrm{~cm}^{-1}$ was dominated by the glycosidic linkage $\mathrm{v}(\mathrm{C}-\mathrm{O}-\mathrm{C})$ stretching vibration contribution (Fig. 2a-f).

\section{Discussion}

Recently, EPSs have great potential as antitumor drug, as recent treatment strategies showed limitations of severe side effects and multidrug resistance occurred (Romanenko et al. 2008). Marine microbes have turned out to be well known and novel sources of EPSs, albeit numerous known marine bacteria can produce EPSs. Few of them are of biotechnological significance, so the search of EPSs that may have imaginative applications is still of potential intrigue (Casillo et al. 2018). While trying to get the marine bacterial strains, we separated from various areas and assessed based on the productivity of the EPSs. From the 20 marine EPSs, the promising $\mathrm{IC}_{50}$ of 11 EPSs (M1, M3, M6, M15, M19, E2, E4, E10, S5, S7, and S11) were 524.0, 549.0, 562.0, 501.0, 309.0, 537.0, 630.9, 549.0, 436.0, 389.0, and 407.0 $\mu \mathrm{g} /$ $\mathrm{mL}$, individually. However, the remaining EPSs showed moderate anti-proliferative activities (Table 2). A few polysaccharides significantly inhibit the development of malignancy cells as illustrated by Huang (2013), while other polysaccharides demonstrated different functions. For instance, the polysaccharides from Ganoderma lucidum fundamentally decreased tumor cells in vitro (Zhao et al. 2010); on the other hand, polysaccharide from Pleurotus sp. mycelium demonstrated its antioxidant activities in vitro (Liu et al. 2010). Marine bacterial strain GWS-BW-H8hM was accounted for to hinder development of gastric cell line (HM02), liver cell line (HepG2), and bosom cell line (MCF7) (Bitzer et al. 2006). EPSs and sulfated polysaccharides from Halomonas stenophila sp. repressing hypersaline condition have likewise been accounted for their pro-apoptotic effects for
T-leukemia cells (Ruiz-Ruiz et al. 2011; Xu et al. 2014). These show that MGA2, MSA1, E4, SGA3, and NRC7 are acidic sulfated heteropolysaccharides. MGA2, MSA1, E4, SGA3, and NRC7 are comprised of different monosaccharides including glucose, mannose, galactose, glucouronic acid, and mannouronic acid. A lot of marine bacteria are encompassed by EPSs, which may help bacterial groups to endure extremes of saltiness, temperature, and nutrient availability (Casillo et al. 2018). In view of the chemical and rheological properties of the EPSs generated by these bacteria, examinations were performed to test their potential applications in biotechnology and ecological protection (Nichols et al. 2005; Guezennec 2002). The item and nature of bacterial EPSs are exceptionally affected by the biological and dietary status (Kumar et al. 2007). Most EPSs created by marine microbes are heteropolysaccharides containing diverse unit of monosugars coordinated in a range of around 10 to compose repeating units (Decho 1990). For the most part, EPSs are straight, with molecular weight from 1 to $3 \times 10^{5} \mathrm{Da}$ (Sutherland 1977). Numerous EPSs are neutral molecules, but the greater parts are polyanionic for the $\mathrm{SO}_{3}{ }^{-}, \mathrm{PO}_{4}{ }^{-}$, and uronic acid presence. The physical properties of EPSs are incredibly influenced by the method for the monosugars arranged and the accumulation of the one polymer chain (Vanhooren and Vandamme 1998). Biological activities of EPSs are depending on its chemical structure and the molecular weight. The presence of rate sugars as ribose and arabinose besides the uronic acid in the order of polygalacturonic, glucouronic, galacturonic acid, and polymers of low molecular weight are important indicators reflecting the antioxidant activity of the EPSs (Roca et al. 2015). Furthermore, in the FTIR spectrum of MGA2, MSA1, E4, SGA3, and NRC7, the characteristic band at $929 \mathrm{~cm}^{-1}$ belonged to the $\beta$-anomeric configuration in MGA2, SGA3, and NRC7 (Synytsya et al. 2003; Zhbankov et al. 1997), and the band at $840 \mathrm{~cm}^{-1}$ was ascribed to $\alpha$-pyranoses in the MSA1 and E4 (Park 1971). Besides, absorption at $1271 \mathrm{~cm}^{-1}$ was assigned to the stretching vibration of $\mathrm{S}=\mathrm{O}$ indicating MGA2, MSA1, E4, SGA3, and NRC7 were sulfated polysaccharides (Percival and Wold 1963). 


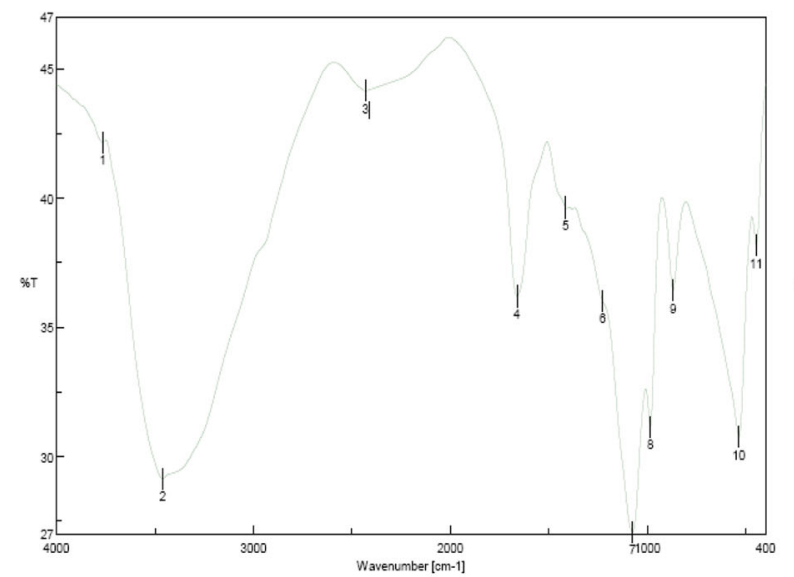

(a)

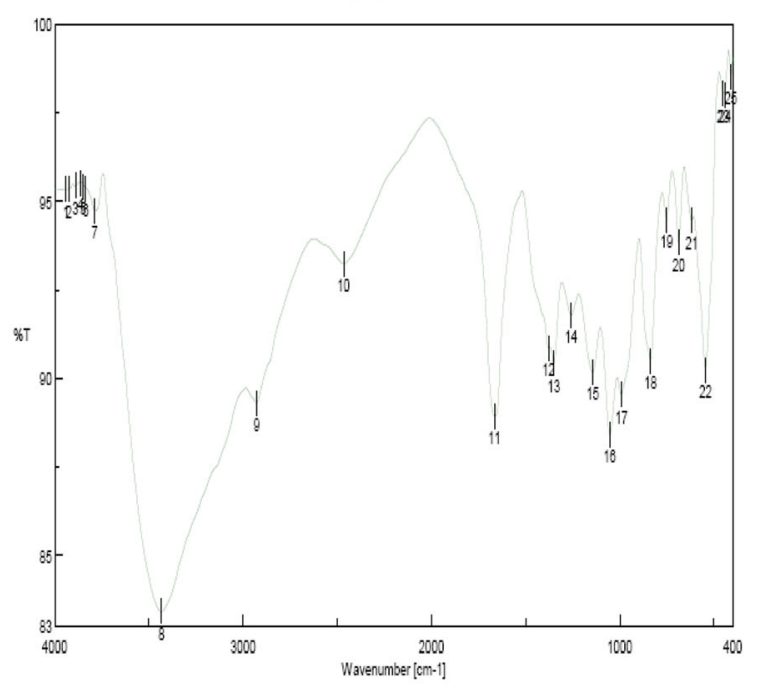

(c)

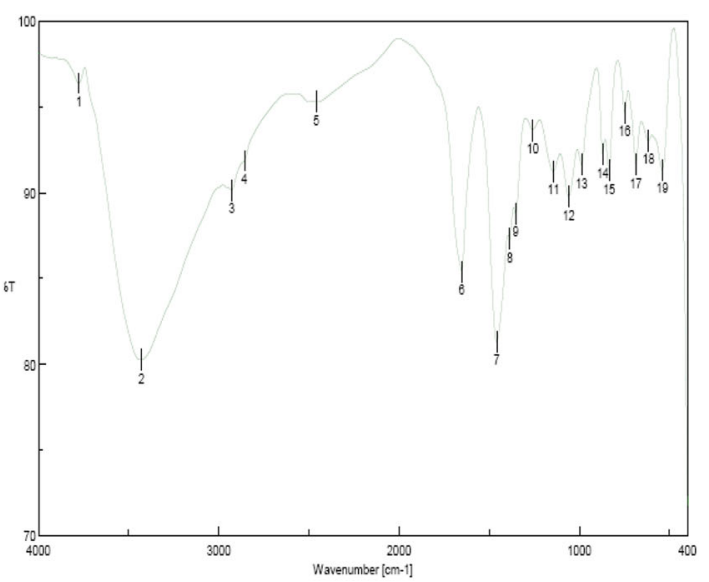

(b)

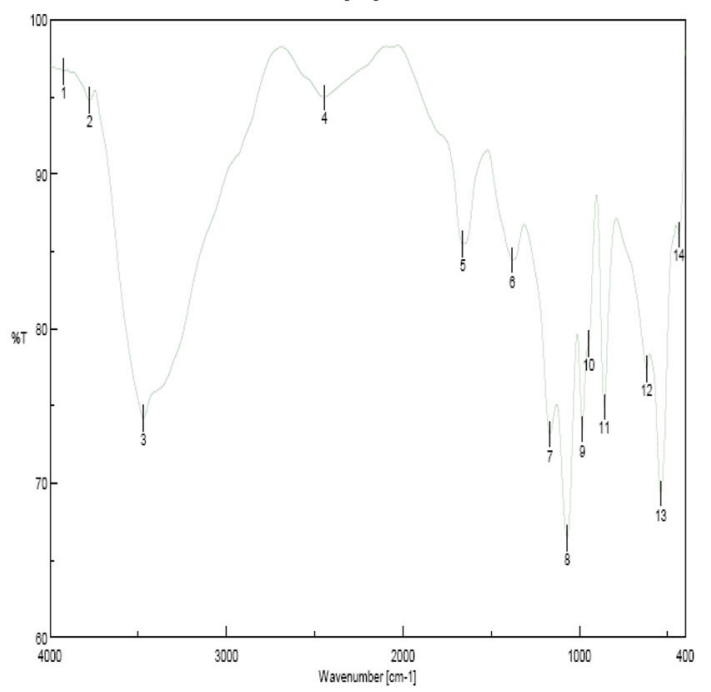

(d)

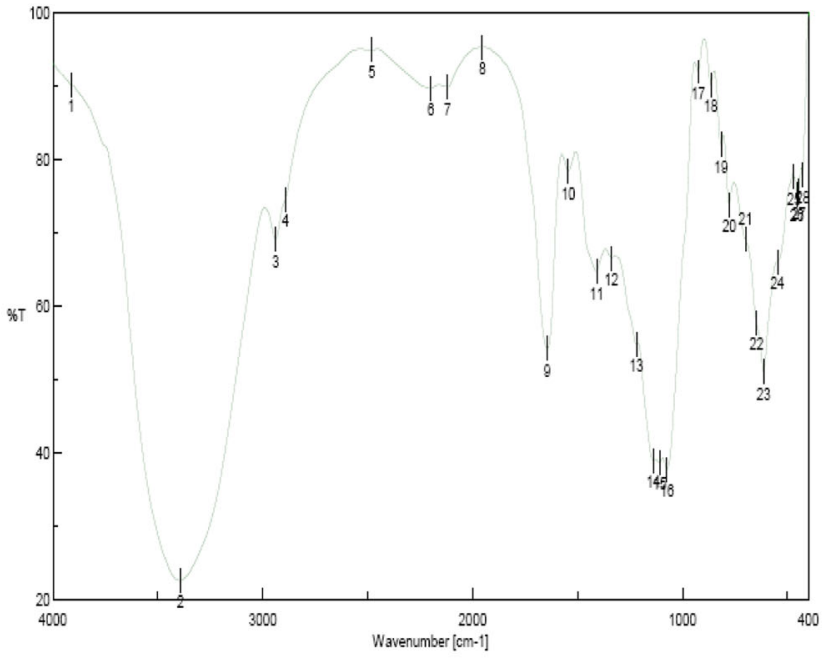

(f)

Fig. 2 Infrared of EPSS a MGA1, b MGA2, c E4, d SGA3, and f NRC7 


\section{Conclusion}

EPSs produced from marine bacteria are very promising for treating the hepatocellular carcinoma HepG2 cells.

\section{Acknowledgements}

National Research Centre (Project number 10050306).

\section{Funding}

All funding from National Research Centre.

\section{Availability of data and materials}

All data and material are available.

\section{Authors' contributions}

All the participant researchers contributed to do this work. All authors read and approved the final manuscript.

\section{Ethics approval and consent to participate}

Not applicable.

\section{Consent for publication}

All the participant researchers are consent for publication.

\section{Competing interests}

The authors declare that they have no competing interests.

\section{Publisher's Note}

Springer Nature remains neutral with regard to jurisdictional claims in published maps and institutional affiliations.

\section{Author details}

${ }^{1}$ Microbial Biotechnology Department, Genetic Engineering and Biotechnology Division, National Research Centre, Dokki, Egypt. ${ }^{2}$ Department of Hormones, National Research Centre, Dokki, Egypt.

Received: 28 August 2018 Accepted: 12 November 2018

Published online: 04 December 2018

\section{References}

Bitter T, Muir HM (1962) A modified uronic acid carbazole reaction. Anal Biochem 4:330-334

Bitzer J, Grosse T, Wang L, Lang S, Beil W, Zeeck A (2006) New aminophenoxazinones from a marine Halomonas sp. fermentation, structure elucidation, and biological activity. J Antibiot (Tokyo) 59:86-92

Bradford MM (1976) A rapid and sensitive method for the quantitation of microgram quantities of protein utilizing the principle of protein-dye binding. Anal Biochem 72:248-254

Cai Q, Li Y, Pei G (2017) Polysaccharides from Ganoderma lucidum attenuate microglia-mediated neuroinflammation and modulate microglial phagocytosis and behavioural response. J Neuroinflammation 14(1):63

Cappuccino JG, Sherman N (2004) Microbiology: a laboratory manual. Pearson Education (Singapore), Indian Branch, New Delhi

Casillo C, Lanzetta R, Parrilli M, Corsaro MM (2018) Exopolysaccharides from marine and marine extremophilic bacteria: structures, properties, ecological roles and applications. Mar Drugs 16:1-34

Decho AW (1990) Microbial exopolymer secretions in ocean environments: their role(s) in food webs and marine processes. In: Barnes M (ed) Oceanography and Marine Biology: an Annual Review. Aberdeen University Press, Aberdeen, pp 73-153

Drake CG, Antonarakis ES (2010) Update: immunological strategies for prostate cancer. Curr Urol Rep 11:202-207

Dubois M, Gilles KA, Hamilton JK, Rebers PA, Smith F (1956) Colorimetric method for determination of sugars and related substances. Anal Chem 28:350-356

Fenical W (1993) Chemical studies of marine bacteria: developing a new resource. Chem Rev 93:1673-1683

Guezennec J (2002) Deep-sea hydrothermal vents: a new source of innovative bacterial exopolysaccharides of biotechnological interest? J Inder Microbio Biotechnol 29:204-208
Hayakawa M, Nonomura H (1987) Humic acid-vitamin agar, a new medium for the selective isolation of soil actinomycetes. J of Fermentation Technology 65(5):501-509

Huang T, Lin J, Cao J, Zhang P, Bai Y, Chen G, Chen K (2012) An exopolysaccharide from Trichoderma pseudokoningii and its apoptotic activity on human leukemia K562 cells. Carbohydr Polym 89:701-708

Huang W (2013) Anticancer effect of plant-derived polysaccharides on mice. J of Cancer Ther 4:500-503

Jiang ZD, Jensen PR, Fenical W (1999) Lobophorins A and B, new antiinflammatory macrolides produced by a tropical marine bacterium. Biog Med Chem Lett 9(14):2003-2006

Jun L, Jiangguang L, Hong Y, Yi S, Zhaoxin L, Zeng X (2009) Production, characterization and anti-oxidant activities in vitro of exopolysaccharides from endophytic bacterium Paenibacillus polymyxa EJS-3. Carbohydr Polym 78:275-281

Kumar AS, Mody K, Jha B (2007) Bacterial exopolysaccharides - a perception. J Basic Microbiol 47:103-117

Liu XN, Zhou B, Lin RS, Jia L, Deng P, Fan KM, Wang GY, Wang L, Zhang JJ (2010) Extraction and antioxidant activities of intracellular polysaccharide from Pleurotus sp. mycelium. Inter J Biol Macromol 47:116-119

Maidak BL, Olsen GJ, Larson N, Overbeek MJ, Woese CR (1997) The ribosomal database project (RDP). Nucleic Acid Res 25(1):109-110

Miranda CCBO, Dekker RFH, Serpeloni JM, Fonseca EAI, Colus IMS, Barbosa AM (2008) Anticlastogenic activity exhibited by botryosphaeran, a new exopolysaccharide produced by Botryosphaeria rhodina MAMB-05. Inter J Biol Macromol. 42:172-177

Nichols CA, Guezennec J, Bowman JP (2005) Bacterial exopolysaccharides from extreme marine environments with special consideration of the southern ocean, sea ice, and deep-sea hydrothermal vents: a review. Mar Biotechnol 7:253-271

Park FS (1971) Application of I.R. spectroscopy in biochemistry, biology, and medicine. Plenum Press, New York

Peng Q, Li M, Xue F, Liu H (2014) Structure and immunobiological activity of a new polysaccharide from Bletilla striata. Carbohydr Polym 107:119-123

Percival E, Wold JK (1963) The acid polysaccharide from the green seaweed Ulvo lactuca Part II The site of the ester sulphate. J The Chem Soc 34:5459-5468

Randall RC, Phillips GO, Williams PA (1989) Fractionation and characterization of gum from Acacia senegal. Food Hydrocoll 3(1):65-75

Ray B (2006) Polysaccharides from Enteromorpha compressa: isolation, purification and structural features. Carbohydr Polym 66:408-416

Repetto G, del Peso A, Zurita JL (2008) Neutral red uptake assay for the estimation of cell viability/cytotoxicity. Nat Protoc 3(7):1125-1131

Roca C, Alves VD, Freitas F, Reis MAM (2015) Exopolysaccharides enriched in rare sugars: bacterial sources production and applications. Front Microbiol 6:1-7

Romanenko LA, Uchino M, Kalinovskaya NI, Mikhailov W (2008) Isolation, phylogenetic analysis and screening of marine mollusc-associated bacteria for antimicrobial, hemolytic and surface activities. Microbiol Res 163:633-644

Ruiz-Ruiz C, Srivastava GK, Carranza D, Mata JA, Llamas I, Santamaria M, Quesada E, Molina IJ (2011) An exopolysaccharide produced by the novel halophilic bacterium Halomonas stenophila strain B100 selectively induces apoptosis in human T leukaemia cells. Applied Microbiol and Biotechnology 89:345-355

Shah B, Bhowmick S (2006) Evaluation of important treatment parameters in supraphysiological thermal therapy of human liver cancer HepG2 cells. Ann Biomed Eng 34:1745-1757

Shene C, Canquil N, Bravo S, Rubilar M (2008) Production of the exopolysacchzrides by Streptococcus thermophilus: effect of growth conditions on fermentation kinetics and intrinsic viscosity. Inter J of Food Microbiol 124(3):279-284

Sudhamani SR, Tharanathan RN, Prasad MS (2004) Isolation and characterization of an extracellular polysaccharide from Pseudomonas caryophylli CFR 1705. Carbohydr Polym 56:423-427

Sutherland IW (1977) Microbial exopolysaccharide synthesis. In: Sanford PA Laskin A (eds) Extracellular Microbial Polysaccharides, vol 45. American Chemical Society, Washington, pp 40-57

Synytsya A, Čopíková J, Matějka P, Machovič V (2003) Fourier transforms Raman and infrared spectroscopy of pectins. Carbohydr Polym 54:97-106

Tamura K, Dudley J, Nei M, Kumar S (2007) MEGA4: molecular evolutionary genetics analysis (MEGA) software version 4.0. Mol Biol Evol 24:1596-1599

Terho TT, Hartiala K (1971) Method for determination of the sulfate content of glycosaminoglycans. Anal Biochem 41:471-476

Vanhooren PT, Vandamme EJ (1998) Biosynthesis, physiological role, use and fermentation process characteristics of bacterial exopolysaccharides. Rec Res Devel Ferment Bioeng 1:253-299 
Wang J, Zhao X, Yang Y, Zhao A, Yang Z (2014) Characterization and bioactivities of an exopolysaccharide produced by Lactobacillus plantarum YW32. Inter J Biol Macromol 74:119-126

Wani MC, Taylor HL, Wall ME, Coggon P, McPhail AT (1971) Plant antitumor agents. VI. The isolation and structure of taxol, a novel antileukemic and antitumor agent from Taxus brevifolia. J Am Chem Soc 93:2325-2327

Xu C, Zhang C, Tian Z, Zheng H, Yu X (2014) Comparison of the antitumor activity of polysaccharides extracted by boiling water and enzyme assistance from Ganoderma lucidum. Engine Scie 12(1):21-23

Xu CL, Wang YZ, Jin ML, Yang XQ (2009) Preparation, characterization and immunomodulatory activity of selenium-enriched exopolysaccharide produced by bacterium Enterobacter cloacae Z0206. Bioresour Technol 100:2095-2097

Yang B, Xiao B, Sun T (2013) Antitumor and immunomodulatory activity of Astragalus membranaceus polysaccharides in $\mathrm{H} 22$ tumor-bearing mice. Inter J Biol Macromol 62:287-290

Yang J, Li X, Xue Y, Wang N, Liu W (2014) Anti-hepatoma activity and mechanism of corn silk polysaccharides in $\mathrm{H} 22$ tumor-bearing mice. Inter J Biol Macromol 64:276-280

You LJ, Gao Q, Feng MY, Yang B, Ren JY, Gu LJ, Cui C, Zhao MM (2013) Structural characterisation of polysaccharides from Tricholoma matsutake and their antioxidant and antitumour activities. Food Chem 138:2242-2249

Zhao LY, Dong YH, Chen GT, Hu QH (2010) Extraction, purification, characterization and antitumor activity of polysaccharides from Ganoderma. Carbohydr Polym 80:783-789

Zhbankov RG, Adnànov VM, Marchewka MK (1997) Fourier transform IR and Raman spectroscopy and structure of carbohydrates. J Mol Struct 436/ 437:637-636

\section{Submit your manuscript to a SpringerOpen ${ }^{\circ}$ journal and benefit from:}

- Convenient online submission

- Rigorous peer review

- Open access: articles freely available online

- High visibility within the field

- Retaining the copyright to your article

Submit your next manuscript at $\boldsymbol{\nabla}$ springeropen.com 